\title{
Tissue composition of carcass, meat quality and fatty acid content of ducks of a commercial breeding line at different age
}

\begin{abstract}
Composition of carcasses and meat quality were investigated in ducks from A44 strain from the $7^{\text {th }}$ to $9^{\text {th }}$ week of life. Drakes and ducks in the $8^{\text {th }}$ and $9^{\text {th }}$ week of age were characterized by significantly higher dressing percentage and better musculature than in the $7^{\text {th }}$ week. Fatness of drakes and ducks carcasses significantly increased in the $8^{\text {th }}$ and $9^{\text {th }}$ week of rearing and the meat: fat ratios were similar to the results obtained in ducks of the $7^{\text {th }}$ week of age. Basing on pH values, faulty meat of PSE and DFD was not found. Protein and fat contents in breast and leg muscles of ducks in the tested periods of rearing indicated significantly higher nutrition value of A44 ducks' meat in the $9^{\text {th }}$ than in the $7^{\text {th }}$ and $8^{\text {th }}$ week of age. The fatty acid profile analysis for ducks' muscles and fat showed that the tissues had a relatively good nutritive and processing value as regard higher unsaturated than saturated fatty acid content and high content of oleic and linoleic fatty acids. Better PUFA n-6/n-3 ratios in breast muscles and skin with subcutaneous fat than in leg muscles and abdominal fat were found.
\end{abstract}

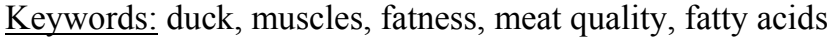

\section{Zusammenfassung}

Titel der Arbeit: Schlachtkörperzusammensetzung, Fleischqualität und Fettsäuremuster bei Enten mit unterschiedlichem Alter

Untersucht wurden die Schlachtkörperzusammensetzung, die Fleischqualität und das Fettsäuremuster einzelner Körpergewebe von Enten im Alter von 7, 8 und 9 Wochen. Die Tiere gehörten zum Zuchtstamm A44 von Peking Enten. Erpel und Enten im Alter von 8 und 9 Wochen erreichten ein höheres Schlachtgewicht und eine bessere Bemuskelung als die 7 Wochen alten Tiere. Die Verfettung des Schlachtkörpers bei Erpeln und Enten erhöhte sich signifikant in der 8. Aufzuchtwoche um 4,1\% und in der 9. um 2,8\%. Das Verhältnis Fleisch zu Fett war jedoch ähnlich wie bei den 7 Wochen alten Tieren. Basierend auf den pH-Werten fanden sich keine Anzeichen für PSE oder DFD. Die 9 Wochen alten Enten zeigten wesentlich bessere Eiweiß- und Fettgehalte und damit Nährwerte in den Brust- und Schenkelmuskeln als die 7 bzw. 8 Wochen alten Tiere. Das Fettsäureprofil der Muskel- und Fettgewebe wies bei diesen relativ gute Gesundheits- und Verwertungswerte auf, was durch einen höheren Anteil ungesättigter gegenüber gesättigten Fettsäuren sowie einen hohen Anteil von Öl- und Linolsäure begründet war. Das bessere PUFA Verhältnis n-6/n-3 fand sich im Brustmuskel und in der Haut mit subkutanem Fett im Vergleich zum Schenkelmuskel und Bauchfett.

Schlüsselwörter: Ente, Bemuskelung, Verfettung, Fleischqualität, Fettsäuren

\section{Introduction}

Physicians have started to recommend people to limit the consumption of red meat in favour of poultry meat due to the increase in cardiovascular pathologies in human after consuming mainly beef meat (PFEUFFER, 2001). Therefore, in many countries we can observe the continuous increase in the consumption of poultry meat. The dietetic quality of carcasses - and especially of meat - is becoming more and more important also in ducks (PINGEL and JUNG, 1979; BAGLIACCA et al., 1997; ISGUZAR et al., 2002; WAWRO et al., 2004). Ducks are primarily kept for meat production. 
Consequently, the main aim in duck-breeding is to improve musculature (PINGEL and JUNG, 1979; PINGEL and HEIMPOLD, 1983; SHAHIN et al., 2000; KSIAZŻKIEWICZ, 2003). Ducks from paternal pedigree strain A44 are selected in order to increase their musculature and decrease fatness (MARUYAMA et al., 1999; MAZANOWSKI et al., 2001; WAWRO et al., 2004). However, POWELL (1992) stated that the intensive selection may result in worsening of nutrition value of meat. Scientific research, which were carried out on meat ducks, mainly focused on dressing percentage (PINGEL and TRETTNER, 1987; BOCHNO et al., 1992; KISIEL, 2001; KOKOSZYŃSKI et al., 2002; KISIEL and KSIĄŻKIEWICZ, 2004; KOKOSZYŃSKI and KORYTKOWSKA, 2005), chemical composition of muscles (BONS et al., 1998; WITKIEWICZ, 2000; MAZANOWSKI and KSIAZŻKIEWICZ, 2004; ADAMSKI, 2005), physical and chemical meat characteristics - pH, water holding capacity and colour (KISIEL, 2001; KISIEL and KSIĄŻKIEWICZ, 2004; ADAMSKI, 2005; ADAMSKI et al., 2005). Moreover, one of the indicators specifying meat quality is the content of unsaturated (mono- and polyunsaturated) and saturated fatty acids (BERNACKI and ADAMSKI, 2001; KOKOSZYŃSKI et al., 2002; WITKIEWICZ and KONTECKA, 2002). Among the unsaturated fatty acids, exogenous unsaturated fatty acids (linoleic and linolenic) are particularly valuable.

The aim of this study was to assess and compare carcass tissue composition and meat quality of drakes and ducks from A44 strain reared up to the $9^{\text {th }}$ week of life.

\section{Materials and Methods}

The experiment was carried out on 40 drakes and 40 ducks from A44 strain, reared for 9 weeks in 4 repeats - each of 20 birds, divided according to sex. A44 is a strain of Pekin ducks imported from the United Kingdom. The birds were kept under the conditions recommended for broiler ducks and fed ad libitum with mixtures, which nutritive values applied in the successive rearing periods are presented in Table 1.

Table 1

Chemical composition of mixtures, \% (Chemische Zusammensetzung des Mischfutters, \%)

\begin{tabular}{lcc}
\hline Item & \multicolumn{2}{c}{ Feeding periods, week - Type of mixture } \\
& $0-3-\mathrm{KB} 1$ & $4-9-\mathrm{KB} 2$ \\
\hline Metabolizable energy, MJ & 11.93 & 12.31 \\
Crude protein, \% & 20.72 & 17.53 \\
Crude fibre, \% & 3.09 & 3.31 \\
Crude fat, \% & 2.90 & 3.40 \\
Crude ash, \% & 6.40 & 6.00 \\
Lysine, \% & 1.09 & 0.87 \\
Methionine, \% & 0.50 & 0.44 \\
Tryptophan, \% & 0.22 & 0.20 \\
Ca, \% & 1.03 & 0.94 \\
$\mathrm{P}, \%$ & 0.46 & 0.43 \\
\hline
\end{tabular}

Chemical content of mixtures for ducks was in accordance with norms (SMULIKOWSKA, 1996). During first two weeks of rearing each $100 \mathrm{~kg}$ of feed mixture was supplemented with $25 \mathrm{~g}$ of Polfamix $\mathrm{Z}$ and with $10 \mathrm{~g}$ of Polfasol $\mathrm{B}$ compositum, and from the $8^{\text {th }}$ day of life to the end of rearing ducks were offered the mineral mixture containing MM-D, chalk and gravel $(1: 1: 4)$ in separate feeders. In the $7^{\text {th }}, 8^{\text {th }}$ and $9^{\text {th }}$ week of males and females' life carcasses dissection was carried out applying the method described by ZIOŁECKI and DORUCHOWSKI (1989). In each 
week of rearing, 5 males and 5 females were chosen with the body weight similar to the average specimen weight of particular sex within the group.

After plucking and chilling for about $18 \mathrm{~h}$, the carcasses were eviscerated, separating breast, thigh and shank muscles, skin with subcutaneous fat and abdominal fat from the whole carcass. Apart from that, breast, thigh and shank muscles' $\mathrm{pH}_{15^{\prime}}$ was marked in 15 min from the slaughtering, using a spearhead electrode OSH 1280 linked to a $\mathrm{CP}-401 \mathrm{pH}-$ meter. The electrode was placed at the $45^{\circ}$-angle in the midway through the examined muscles. Values of $\mathrm{pH}$ were read from a LCD display with an accuracy of 0.01. After the 18-hour carcass chilling the measurements were repeated and $\mathrm{pH}_{24 \mathrm{~h}}$ value was marked. After the dissection analysis breast muscles as well as thigh and shank muscles were taken from the half of each carcass in order to assess physicochemical characteristics of the meat. Each bird's breast and leg muscles were minced and homogenized separately in the food processor. Then, the samples were divided into three parts. One of them was placed in tight-closed containers in $4{ }^{\circ} \mathrm{C}$, from where samples were taken to test water holding capacity and water content. Water holding capacity of breast and leg muscles was marked with GRAU and HAMM's method (1952). The samples of tested muscles were weighed (approximately $300 \mathrm{mg}$ ), and placed at a tissue paper Whatman 4 between 2 glass plates. The samples prepared in this way were pressed by a $2 \mathrm{~kg}$ weight for $5 \mathrm{~min}$. After that, the contours of muscle samples obtained before and after using the pressure were drawn and computed with the help of a planimeter. The second part of previously homogenized samples of breast and leg muscles, separate for each bird, was used to analyze their chemical composition. Muscle chemical composition was tested with standard methods. Moisture and crude protein contents were determined following the AOAC Official Methods 39.1.02 and 39.1.19, respectively, while fat content using Soxhlet's method with the help of Büchi 810 device following the Polish Norms PN-ISO 1444. The meat colour was detemined by means of the Minolta apparatus. The third part of the samples was used to determine fatty acids by gas chromatography following the Polish Norms PN-EN ISO 5508. The samples were examined in the form of methyl esters prepared by Polish Norms PN-EN ISO 5509.

The traits have been analysed for the described set of animals and the analysis was based on the following model:

$$
\mathrm{y}_{\mathrm{ijl}}=\mathrm{m}+\mathrm{A}_{\mathrm{i}}+\mathrm{B}_{\mathrm{j}}+\mathrm{AB}_{\mathrm{ij}}+\mathrm{e}_{\mathrm{ijl}}
$$

where: $y_{i j 1}$ - value of the trait, $m$ - mean of the population, $A_{i}-$ effect of group $i(i=1$, $\ldots, 4), B_{j}-$ effect of sex, $A_{B}-$ effect of interaction between both factors, $\mathrm{e}_{\mathrm{ij} 1}-$ random error.

Numerical data were processed statistically for analysis of variance and significant differences using Tukey's test.

\section{Results and discussion}

Mean values of preslaughter body weight significantly $(\mathrm{P} \leq 0.05)$ increased for ducks of both sexes, from the $7^{\text {th }}$ to $8^{\text {th }}$ week of life from 3190 to $3540 \mathrm{~g}$ in males and from 3031 to $3292 \mathrm{~g}$ in females; however, in the last week of rearing the body weight slightly decreased compared with the $8^{\text {th }}$ week of rearing (Table 2).

In studies of BERNACKI and ADAMSKI (2001), MAZANOWSKI et al. (2001) and ADAMSKI (2005) eviscerated carcass weight was increasing within the succeeding weeks of rearing. Males and females of A44 strain were characterized by similar carcass 
Table 2

Dissection results of 7-, 8- and 9-week-old ducks

(Ergebnisse der Dissektion der Enten im Alter von 7, 8 und 9 Wochen)

\begin{tabular}{|c|c|c|c|c|c|c|c|c|c|c|}
\hline \multirow[b]{2}{*}{ Trait } & & \multicolumn{3}{|c|}{7 weeks } & \multicolumn{3}{|c|}{8 weeks } & \multicolumn{3}{|c|}{9 weeks } \\
\hline & & 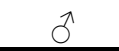 & 웅 & joq & 0 & 9 & ¡오 & 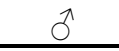 & 울 & d오 \\
\hline \multirow{2}{*}{$\begin{array}{l}\text { Preslaughter body } \\
\text { weight, } \mathrm{g}\end{array}$} & $\mathrm{x}$ & 3190 & 3031 & $3143^{b^{*}}$ & 3540 & 3292 & $3416^{\mathrm{a}^{*}}$ & 3480 & 3282 & $3381^{\mathrm{a}^{*}}$ \\
\hline & $\mathrm{v}$ & 15.0 & 5.82 & 11.0 & 16.9 & 6.9 & 12.6 & 16.1 & 6.5 & 12.0 \\
\hline \multirow{2}{*}{$\begin{array}{l}\text { Eviscerated carcass } \\
\text { with neck weight, g }\end{array}$} & $\mathrm{x}$ & 1967 & 1847 & $1907^{b^{*}}$ & 2317 & 2200 & $2259^{\mathrm{a}^{*}}$ & 2285 & 2130 & $2207^{\mathrm{a}^{*}}$ \\
\hline & $\mathrm{v}$ & 22.8 & 7.0 & 15.6 & 15.9 & 6.2 & 11.7 & 16.3 & 7.2 & 12.5 \\
\hline \multirow[t]{2}{*}{$\begin{array}{l}\text { Dressing } \\
\text { percentage, } \%\end{array}$} & $\mathrm{x}$ & 61.7 & 60.9 & $60.7^{\mathrm{B}}$ & 65.5 & 66.8 & $66.2^{\mathrm{A}}$ & 65.7 & 64.9 & $65.3^{\mathrm{A}}$ \\
\hline & $\mathrm{v}$ & 1.3 & 0.9 & 1.5 & 1.3 & 0.9 & 1.5 & 0.9 & 0.7 & 1.0 \\
\hline \multirow[t]{2}{*}{$\begin{array}{l}\text { Breast muscle } \\
\text { content, } \%\end{array}$} & $\mathrm{x}$ & 14.5 & 14.4 & $14.4^{\mathrm{b}}$ & 16.9 & 15.5 & $16.2^{\mathrm{a}}$ & 17.8 & 17.0 & $17.4^{\mathrm{a}}$ \\
\hline & $\mathrm{v}$ & 6.7 & 4.9 & 5.5 & 12.1 & 9.6 & 11.1 & 8.3 & 8.9 & 8.3 \\
\hline \multirow[t]{2}{*}{$\begin{array}{l}\text { Leg muscle } \\
\text { content, } \%\end{array}$} & $\mathrm{x}$ & 15.3 & 15.2 & $15.2^{\mathrm{a}}$ & 13.4 & 14.8 & $14.1^{\mathrm{b}}$ & 12.5 & 15.4 & $14.0^{\mathrm{b}^{*}}$ \\
\hline & $\mathrm{V}$ & 8.5 & 5.6 & 6.7 & 2.9 & 1.6 & 5.8 & 4.9 & 7.3 & 12.6 \\
\hline \multirow[t]{2}{*}{$\begin{array}{l}\text { Skin with subcuta- } \\
\text { neous fat content, \% }\end{array}$} & $\mathrm{x}$ & 27.4 & 27.5 & $27.4^{\mathrm{b}}$ & 31.3 & 30.6 & $30.9^{\mathrm{a}}$ & 31.8 & 27.7 & $29.8^{\mathrm{a}^{*}}$ \\
\hline & $\mathrm{v}$ & 10.8 & 10.9 & 10.1 & 9.1 & 9.6 & 8.7 & 11.1 & 4.5 & 11.1 \\
\hline \multirow[t]{2}{*}{$\begin{array}{l}\text { Abdominal fat } \\
\text { content, } \%\end{array}$} & $\mathrm{x}$ & 1.1 & 0.8 & 0.9 & 1.4 & 1.6 & 1.5 & 1.5 & 1.0 & 1.3 \\
\hline & $\mathrm{v}$ & 44.3 & 36.4 & 42.3 & 35.5 & 21.7 & 27.6 & 39.0 & 25.2 & 38.5 \\
\hline Meat : fat ratio & $\mathrm{x}$ & $1.04: 1$ & $1.04: 1$ & $1.04: 1$ & 0.91:1 & $0.95: 1$ & $0.93: 1$ & $0.89: 1$ & $1.13: 1$ & $1.01: 1$ \\
\hline Meat : bone ratio & $\mathrm{x}$ & $0.87: 1$ & 0.89:1 & $0.88: 1$ & $1.06: 1$ & $1.02: 1$ & $1.04: 1$ & $1.07: 1$ & $1.08: 1$ & $1.07: 1$ \\
\hline Fat : bone ratio & $\mathrm{x}$ & $0.84: 1$ & $0.85: 1$ & $0.85: 1$ & $1.16: 1$ & $1.08: 1$ & $1.12: 1$ & $1.19: 1$ & $0.95: 1$ & $1.07: 1$ \\
\hline
\end{tabular}

weight in $9^{\text {th }}$ week of rearing to the research of ADAMSKI (2005) and larger carcass weight than proved by BERNACKI and ADAMSKI (2001). Similarly to duck body weight, significantly $(\mathrm{P} \leq 0.05)$ larger dressing percentage was also stated in the $8^{\text {th }}$ $(66.2 \%)$ and $9^{\text {th }}(65.3 \%)$ week of life. Significant differences of dressing percentage between ducks and drakes was not found. Reported by MAZANOWSKI et al. (2001) four-strain crossbreds of ducks with gene share of A44 birds were distinguished by increasing dressing percentage during rearing from 66.0 to $68.7 \%$. However, in this study dressing percentage increased by $5.5 \%$ between the $7^{\text {th }}$ and $8^{\text {th }}$ week of rearing and then decreased by $1.5 \%$ in the last slaughter age. Dressing percentage of A44 birds of 8-week of age obtained by WITKIEWICZ (2001) and ADAMSKI (2005) was larger for males and females than in this study.

Breast muscle content was significantly $(\mathrm{P} \leq 0.05)$ increasing from 14.4 in the $7^{\text {th }}$ week to $17.4 \%$ in the $9^{\text {th }}$ week of rearing, while thigh and shank muscle content was significantly $(\mathrm{P} \leq 0.05)$ decreasing from 15.2 to $14.0 \%$, respectively (Table 2$)$. In the $7^{\text {th }}$ and $8^{\text {th }}$ week of life, the contents of breast and leg muscles of males' carcasses were similar to those of females (differences statistically insignificant). Moreover, in the $8^{\text {th }}$ and $9^{\text {th }}$ week of rearing breast muscle content was larger $(\mathrm{P} \leq 0.05)$, whereas thigh and shank muscle content was smaller $(\mathrm{P} \leq 0.05)$ in males than those in females. Similar results showing intensive growth of breast muscles during the rearing period were also found in other studies (PINGEL, 1990; BONS et al., 1998; BERNACKI and ADAMSKI 2001; MAZANOWSKI et al., 2001; ADAMSKI, 2005). Breast muscle content for A44 drakes and ducks in studies of BERNACKI and ADAMSKI (2001) 
was increasing from $12.4 \%$ in the $7^{\text {th }}$ week to $16.2 \%$ in the $9^{\text {th }}$ week, while leg muscle content was decreasing from 12.2 to $10.9 \%$, respectively, however the muscle contents were considerably smaller than those stated in the research. Higher breast muscle content than leg muscle content in the $8^{\text {th }}$ and $9^{\text {th }}$ week of rearing were found both in males and females. Peking ducks reared up to the $7^{\text {th }}$ week abroad (BONS et al., 1999) were characterized by similar breast $(9.7 \%)$ and leg content $(9.4 \%)$, in contrast with this research. Skin with subcutaneous fat content during ducks and drakes rearing considerably increased ( $\mathrm{P} \leq 0.05$ from 27.4 to $29.8 \%$, similarly to abdominal fat content from 0.9 to $1.3 \%$ (differences statistically insignificant). Males were characterized by larger contents of skin with subcutaneous fat and abdominal fat than females, especially in the last week of rearing. In case of skin with subcutaneous fat significant $(\mathrm{P} \leq 0.050)$ differences between sexes in the $9^{\text {th }}$ week were found. In comparison with the paper, four-strain crossbreds of ducks with gene share of A44 were characterized by similar skin with subcutaneous fat content (from 29.3 to $30.6 \%$ ) in the $7^{\text {th }}, 8^{\text {th }}$ and $9^{\text {th }}$ week (MAZANOWSKI et al., 2001). Lower content of the carcass component was found in other study (BERNACKI and ADAMSKI, 2001) for 7-, 8and 9-week-old A44 ducks of both sexes (from 24.1 to $25.6 \%$ ), in contrast to this study. Moreover, interactions between particular carcass components indicated that meat : fat ratio ranged from $0.93: 1$ to $1.04: 1$, meat to bone ratio from $0.88: 1$ to $1.07: 1$ and fat to bone ratio from $0.85: 1$ to $1.12: 1$. Thus, the results showed relatively slight differentiation between the analysed tissue contents.

Meat quality of ducks was assessed on the basis of chemical composition, $\mathrm{pH}$ values, water holding capacity and meat colour of breast and leg muscles (Table 3 ).

In all rearing periods $\mathrm{pH}$ values of breast, thigh and shank muscles were becoming smaller $24 \mathrm{~h}$ after slaughtering, which showed that the glycolysis process was occurring in a normal way. The $\mathrm{pH}$ values of breast as well as thigh and shank muscles in the $7^{\text {th }}, 8^{\text {th }}$ and $9^{\text {th }}$ week of life (5.71 to 6.30) pointed that ducks of A44 strain did not possess the quality of PSE or DFD type. In the present research the water holding capacity ranged from 8.7 to $19.1 \%$ for breast muscles, whereas for thigh and shank muscles it was slightly higher and amounted to 9.9-22.9\% (Table 3). In both tested muscles the water holding capacity in the $7^{\text {th }}$ week of age was significantly $(\mathrm{P} \leq 0.05)$ larger than in the $8^{\text {th }}$ and $9^{\text {th }}$ week of ducks' age. Higher $\mathrm{pH}$ values in leg muscles than in breast muscles caused the increase of water holding in leg muscles. Simultaneously, bigger water holding in leg muscles was a result of increased water holding capacity, in comparison with the trait in breast muscles. The characteristic of both breast and leg muscles in the $7^{\text {th }}$ week of rearing was significantly $(\mathrm{P} \leq 0.05)$ higher than that in the $8^{\text {th }}$ and $9^{\text {th }}$ week of rearing, which means that muscles of 7-week-old ducks had better water holding capacity than 8- or 9-week-old birds. It should be noticed that meat with a high $\mathrm{pH}$ value, like in leg muscles, was characterized by favourable water holding capacity and was less juicy (GRABOWSKI, 2002).

The water content of breast muscles in the $7^{\text {th }}$ week of birds' life was $77.1 \%$ and in the $9^{\text {th }}$ week of their lives $-74.8 \%$, whereas the water content of thigh and shank muscles was lower and amounted to 74.8 and $72.0 \%$, respectively (Table 3 ). The water content in breast muscles in 9-week-old drakes and ducks from A44 pedigree strain was $74.8 \%$ (ADAMSKI, 2005) and was similar to that in this study. WITKIEWICZ (2000) marked a slightly lower water content for breast muscles of A44 ducks. Drakes and ducks had similar chemical composition of muscles, however slightly more water and 
protein but less fat in breast and leg muscles were found in drakes than ducks. Together with age the protein content in breast muscles grew significantly $(\mathrm{P} \leq 0.05)$ from 19.4 to $20.7 \%$, similarly to leg muscles protein content from 18.7 to $19.5 \%$.

Table 3

Physical and chemical composition of breast and leg muscles in 7-, 8- and 9-week-old ducks (Physikalischchemische Eigenschaften der Brust- und Oberschenkelmuskeln bei den Enten im Alter von 7, 8 und 9 Wochen)

\begin{tabular}{|c|c|c|c|c|c|c|c|c|c|c|}
\hline \multirow{2}{*}{ Trait } & & \multicolumn{3}{|c|}{7 weeks } & \multicolumn{3}{|c|}{8 weeks } & \multicolumn{3}{|c|}{9 weeks } \\
\hline & & 0 & ㅇ & 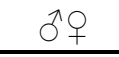 & 0 & q & jot & 0 & 운 & 19+ \\
\hline \multicolumn{11}{|l|}{ Breast muscles } \\
\hline \multirow[t]{2}{*}{$\mathrm{pH}_{15^{\prime}}$} & $\mathrm{x}$ & 6.20 & 6.26 & 6.23 & 6.19 & 6.20 & 6.20 & 6.13 & 6.14 & 6.13 \\
\hline & $\mathrm{v}$ & 4.69 & 0.38 & 3.11 & 1.92 & 4.29 & 3.44 & 2.10 & 2.29 & 2.19 \\
\hline \multirow[t]{2}{*}{$\mathrm{pH}_{24 \mathrm{~h}}$} & $\mathrm{x}$ & 5.75 & 5.77 & 5.76 & 5.75 & 5.74 & 5.74 & 5.75 & 5.71 & 5.73 \\
\hline & $\mathrm{v}$ & 0.92 & 2.63 & 1.95 & 3.07 & 1.42 & 2.67 & 2.40 & 1.89 & 2.12 \\
\hline \multirow{4}{*}{$\begin{array}{l}\text { Water holding } \\
\text { capacity, } \% \\
\text { Meat colour, L }\end{array}$} & $\mathrm{x}$ & 19.10 & 18.20 & $17.50^{\mathrm{a}}$ & 17.80 & 10.60 & $14.20^{\mathrm{b}^{*}}$ & 8.70 & 14.10 & $11.40^{\mathrm{c}^{*}}$ \\
\hline & $\mathrm{V}$ & 2.10 & 1.90 & 2.30 & 1.30 & 5.80 & 4.10 & 6.90 & 3.30 & 5.10 \\
\hline & $\mathrm{x}$ & 31.70 & 34.80 & $33.20^{\mathrm{a}^{*}}$ & 30.20 & 29.70 & $29.90^{\mathrm{b}}$ & 28.40 & 28.90 & $28.60^{\mathrm{b}}$ \\
\hline & $\mathrm{v}$ & 11.70 & 4.30 & 9.30 & 5.30 & 5.90 & 6.00 & 6.30 & 7.60 & 6.60 \\
\hline \multirow{4}{*}{$\begin{array}{l}\text { Water } \\
\text { content, \% } \\
\text { Crude protein } \\
\text { content, } \%\end{array}$} & $\mathrm{x}$ & 77.30 & 76.90 & $77.10^{\mathrm{a}}$ & 77.30 & 76.50 & 76.90 & 74.60 & 74.90 & $74.80^{\mathrm{b}}$ \\
\hline & $\mathrm{V}$ & 0.20 & 0.10 & 1.10 & 0.10 & 0.20 & 0.40 & 0.40 & 0.20 & 0.20 \\
\hline & $\mathrm{x}$ & 19.50 & 19.40 & $19.40^{\mathrm{b}}$ & 19.80 & 19.40 & $19.60^{\mathrm{b}}$ & 21.10 & 20.30 & $20.70^{\mathrm{a}}$ \\
\hline & $\mathrm{V}$ & 0.30 & 0.70 & 0.80 & 0.20 & 0.10 & 0.30 & 0.10 & 0.10 & 0.20 \\
\hline \multirow{2}{*}{$\begin{array}{l}\text { Crude fat } \\
\text { content, } \%\end{array}$} & $\mathrm{x}$ & 3.60 & 3.70 & $3.60^{\mathrm{a}}$ & 3.30 & 3.70 & $3.50^{\mathrm{a}}$ & 2.80 & 2.90 & $2.90^{\mathrm{b}}$ \\
\hline & $\mathrm{v}$ & 0.80 & 1.00 & 1.20 & 1.80 & 1.40 & 1.60 & 1.10 & 1.60 & 1.50 \\
\hline \multicolumn{11}{|c|}{ Thigh and shank muscles } \\
\hline \multirow[t]{2}{*}{$\mathrm{pH}_{15^{\prime}}$} & $\mathrm{x}$ & 6.28 & 6.32 & 6.30 & 6.26 & 6.30 & 6.28 & 6.12 & 6.39 & 6.20 \\
\hline & $\mathrm{v}$ & 0.97 & 1.31 & 2.32 & 1.65 & 5.04 & 3.55 & 1.44 & 1.34 & 1.46 \\
\hline \multirow[t]{2}{*}{$\mathrm{pH}_{24 \mathrm{~h}}$} & $\mathrm{x}$ & 5.91 & 5.94 & 5.92 & 5.91 & 5.92 & 5.91 & 5.96 & 5.97 & 5.96 \\
\hline & $\mathrm{v}$ & 2.53 & 2.13 & 1.59 & 1.40 & 3.70 & 2.80 & 3.01 & 1.02 & 2.56 \\
\hline \multirow{2}{*}{$\begin{array}{l}\text { Water holding } \\
\text { capacity, } \%\end{array}$} & $\mathrm{x}$ & 17.10 & 22.90 & $19.90^{\mathrm{a}^{*}}$ & 13.10 & 9.90 & $11.50^{\mathrm{b}^{*}}$ & 9.80 & 10.30 & $10.00^{\mathrm{b}^{*}}$ \\
\hline & $\mathrm{V}$ & 1.20 & 2.70 & 2.90 & 2.10 & 5.60 & 3.80 & 3.90 & 2.90 & 3.20 \\
\hline \multirow[t]{2}{*}{ Meat colour, L } & $\mathrm{x}$ & 36.30 & 35.30 & $35.80^{\mathrm{a}}$ & 33.20 & 31.30 & $32.20^{\mathrm{b}^{*}}$ & 28.90 & 28.50 & $28.70^{\mathrm{c}}$ \\
\hline & $\mathrm{v}$ & 14.50 & 5.10 & 10.30 & 7.20 & 8.50 & 7.10 & 4.50 & 6.20 & 5.10 \\
\hline \multirow{2}{*}{$\begin{array}{l}\text { Water content, } \\
\%\end{array}$} & $\mathrm{x}$ & 74.90 & 74.70 & $74.80^{\mathrm{a}}$ & 73.40 & 72.80 & $73.10^{\mathrm{b}}$ & 73.10 & 72.70 & $72.90^{\mathrm{b}}$ \\
\hline & $\mathrm{V}$ & 0.60 & 0.50 & 0.80 & 0.30 & 0.40 & 0.40 & 0.20 & 0.50 & 0.30 \\
\hline \multirow{2}{*}{$\begin{array}{l}\text { Crude protein } \\
\text { content, } \%\end{array}$} & $\mathrm{x}$ & 18.90 & 18.40 & $18.70^{\mathrm{b}}$ & 19.10 & 18.80 & $18.90^{\mathrm{b}}$ & 19.70 & 19.30 & $19.50^{\mathrm{a}}$ \\
\hline & $\mathrm{V}$ & 0.20 & 0.10 & 0.30 & 0.50 & 0.10 & 0.80 & 0.70 & 1.00 & 0.90 \\
\hline \multirow{2}{*}{$\begin{array}{l}\text { Crude fat } \\
\text { content, } \%\end{array}$} & $\mathrm{x}$ & 5.30 & 5.90 & $5.60^{\mathrm{a}}$ & 5.50 & 5.60 & $5.50^{\mathrm{a}}$ & 3.10 & 3.20 & $3.20^{\mathrm{b}}$ \\
\hline & $\mathrm{V}$ & 1.00 & 1.90 & 1.80 & 0.90 & 1.20 & 1.30 & 0.80 & 0.60 & 1.20 \\
\hline
\end{tabular}

$a, b=$ Mean values of traits in rows with different letters differ significantly between weeks of rearing $(p \leq 0.05)$

* Significant differences for traits between males and females $(\mathrm{p} \leq 0.05)$

Increasing protein content during rearing of A44 ducks indicated the growth of nutrition value of meat between the $7^{\text {th }}$ and $9^{\text {th }}$ week of life. According to WITKIEWICZ (2000) the protein content in breast muscles of 7-week-old drakes and ducks from A44 strain amounted to $21.1 \%$ and it was higher compared with the results of the present study. Higher protein content in breast $(21.5 \%)$ and leg muscles $(22.5 \%)$ of Peking ducks were also proved by BONS et al. (1998). The fat content of breast muscles for 7-week-old drakes $(1.4 \%)$ and ducks $(2.0 \%)$ from A44 strain marked by WITKIEWICZ (2000) was smaller than the results found in this study, as well as the fat content for 
breast (1.8\%) and leg muscles (3.2\%) of A44 ducks found by ADAMSKI (2005). Drakes' and ducks' breast muscles contained more water and protein but less fat than leg muscles in all assessed periods.

Typical red colour of fresh meat is caused by mioglobine and its derivatives, which constitute about $90 \%$ of meat pigment. Apart from this, to a little extent, the colour results in the presence of hemoglobine and other chemicals. In this study older animals had darker meat colour compared with younger birds. Both breast as well as thigh and shank muscles of 8- and 9-week-old ducks were significantly $(\mathrm{P} \leq 0.05)$ darker than those of 7-week-old ducks. Moreover, breast muscles of ducks in all tested periods (28.6-33.2) were darker than thigh and shank muscles (28.7-35.8). Significant differences between sexes were proved in 7-week-old ducks for breast muscles and in 8 -week-old ducks for thigh and shank muscles.

The evaluation of the composition of fatty acids isolated from muscle tissues is a crucial aspect because lipids are components of meat and have a great effect on its nutritive value. Breast muscles contained more saturated and less unsaturated fatty acids compared with thigh and shank muscles (Table 4).

Among the saturated fatty acids, in both tested muscles palmitic acid $\left(\mathrm{C}_{16: 0}\right)$ had the highest share and it was followed by stearic acid $\left(\mathrm{C}_{18: 0}\right)$, whereas in case of unsaturated acids the order was as follows: oleic acid $\left(\mathrm{C}_{18: 1}\right)$, linoleic acid $\left(\mathrm{C}_{18: 2}\right)$ and palmitoleic acid $\left(\mathrm{C}_{16: 1}\right)$. In the work by BERNACKI and ADAMSKI (2001) carried out on the breast muscles of 8-week ducks from A44 strain palmitic acid constituted $28.7 \%$, stearic acid $15.9 \%$ and oleic acid $35.9 \%$ of muscle fat and the results were higher than in this research. The analysis of the fatty acids profile of all examined tissues showed that oleic acid was the dominating fatty acid and it was followed by palmitic and then linoleic acid. According to BERNACKI and ADAMSKI (2001) oleic acid $(35.9 \%)$ and palmitic acid $(28.7 \%)$ in breast muscles of 8-week-old ducks from A44 strain had the highest share of all fatty acids, which was similar to the results marked in this study. Among the unsaturated fatty acids linolic acid $\left(\mathrm{C}_{18: 2}\right)$ and then oleic acid $\left(\mathrm{C}_{18: 1}\right)$ had the highest share in skin with subcutaneous fat of mallards (KIJANKO et al., 1999). However, in abdominal fat of the mallards the order of fatty acids was the same as in this paper. Among the saturated fatty acids the order of fatty acids in fat of mallards was similar to that presented in this study.

Saturated fatty acids in skin with subcutaneous fat amounted to $27.55 \%$ in 7 -week-old ducks and $25.3 \%$ in the 8 -week-old ducks and unsaturated fatty acids were as follows: 48.4 and $51.7 \%$. The respective values for abdominal fat were: saturated fatty acids 25.3 and $25.9 \%$ while unsaturated fatty acids $-48.6 \%$ and $53.7 \%$. Thus, abdominal fat was characterized by a slightly more favourable ratio of fatty acids compared with the skin with subcutaneous fat. The results were confirmed by the ratio of SFA and PUFA, which was better for abdominal fat in the $7^{\text {th }}$ and $8^{\text {th }}$ week of ducks' lives $(1.76$ and 1.53 , respectively) than skin with subcutaneous fat (1.96 and 1.66). According to the recommendations of World Health Organization (WHO), which determines the nutritional consumption standards of daily amounts of individual kinds of fatty acids, the SFA:PUFA ratio should be $1: 1$ (KULASEK and BARTNIKOWSKA, 1994). The organization also states the PUFA n-6/n-3 ratio, which should amount to $4: 1$. In the present study the best PUFA $n-6 / n-3$ ratio was found in breast muscles, while in the thigh and shank muscles, skin with subcutaneous fat and in abdominal fat the ratio was higher than in breast muscles and it was also almost twice as high as the recommendations. 
Table 4

Fatty acids content of the total fatty acids in breast, thigh and shank muscles, skin with subcutaneous fat and abdominal fat in 7- and 8-week-old ducks from A44 strain, \% (Fettsäurengehalt in den Brust-, Oberschenkelund Unterschenkelmuskeln, in der Haut mit dem Unterhautfett und im Bauchfett bei den Enten im Alter von 7 und 8 Wochen vom A44-Stamm, \%)

\begin{tabular}{|c|c|c|c|c|c|c|c|c|}
\hline \multirow[t]{2}{*}{ Fatty acid } & \multicolumn{2}{|c|}{$\begin{array}{l}\text { Breast } \\
\text { muscle }\end{array}$} & \multicolumn{2}{|c|}{$\begin{array}{c}\text { Thigh and shank } \\
\text { muscle }\end{array}$} & \multicolumn{2}{|c|}{$\begin{array}{c}\text { Skin with } \\
\text { subcutaneous fat }\end{array}$} & \multicolumn{2}{|c|}{$\begin{array}{l}\text { Abdominal } \\
\text { fat }\end{array}$} \\
\hline & 7 & 8 & 7 & 8 & 7 & 8 & 7 & 8 \\
\hline \multicolumn{9}{|c|}{ Saturated fatty acids (SFA) } \\
\hline $\mathrm{C}_{12: 0} \mathrm{x}$ & $\begin{array}{r}0.05 \\
12.40\end{array}$ & $\begin{array}{r}0.03 \\
21.60\end{array}$ & $\begin{array}{r}0.04 \\
15.70\end{array}$ & $\begin{array}{l}\operatorname{tr} \\
0.00\end{array}$ & $\begin{array}{l}\operatorname{tr} \\
0.00\end{array}$ & $\begin{array}{l}\operatorname{tr} \\
0.00\end{array}$ & $\begin{array}{l}0.03 \\
2.16\end{array}$ & $\begin{array}{l}0.04 \\
1.57\end{array}$ \\
\hline $\begin{array}{l}\mathrm{C}_{14: 0} \mathrm{X} \\
\mathrm{V}\end{array}$ & $\begin{array}{r}0.42 \\
15.90\end{array}$ & $\begin{array}{l}0.35 \\
4.32\end{array}$ & $\begin{array}{r}0.33 \\
18.40\end{array}$ & $\begin{array}{r}0.37 \\
18.90\end{array}$ & $\begin{array}{r}0.52 \\
10.20\end{array}$ & $\begin{array}{r}0.44 \\
13.80\end{array}$ & $\begin{array}{r}0.37 \\
17.40\end{array}$ & $\begin{array}{r}0.44 \\
17.50\end{array}$ \\
\hline $\begin{array}{l}\mathrm{C}_{16: 0} \mathrm{X} \\
\mathrm{V}\end{array}$ & $\begin{array}{r}18.40 \\
3.33\end{array}$ & $\begin{array}{r}17.80 \\
3.49\end{array}$ & $\begin{array}{r}17.00 \\
4.73\end{array}$ & $\begin{array}{r}18.20 \\
5.81\end{array}$ & $\begin{array}{r}21.50 \\
4.33\end{array}$ & $\begin{array}{r}19.80 \\
3.78\end{array}$ & $\begin{array}{r}19.40 \\
4.73\end{array}$ & $\begin{array}{r}20,20 \\
5.02\end{array}$ \\
\hline $\begin{array}{l}\mathrm{C}_{18: 0} \mathrm{X} \\
\mathrm{V}\end{array}$ & $\begin{array}{l}5.57 \\
6.70\end{array}$ & $\begin{array}{l}5.76 \\
5.50\end{array}$ & $\begin{array}{l}4.89 \\
5.45\end{array}$ & $\begin{array}{l}4.75 \\
4.07\end{array}$ & $\begin{array}{l}5.32 \\
2.77\end{array}$ & $\begin{array}{l}4.61 \\
2.92\end{array}$ & $\begin{array}{r}5.38 \\
13.60\end{array}$ & $\begin{array}{r}5.11 \\
11.80\end{array}$ \\
\hline $\begin{array}{l}\mathrm{C}_{20: 0} \mathrm{X} \\
\mathrm{V}\end{array}$ & $\begin{array}{l}0.18 \\
3.27\end{array}$ & $\begin{array}{l}0.19 \\
2.03\end{array}$ & $\begin{array}{l}0.53 \\
1.09\end{array}$ & $\begin{array}{l}0.22 \\
2.66\end{array}$ & $\begin{array}{l}0.12 \\
4.95\end{array}$ & $\begin{array}{l}0.43 \\
6.05\end{array}$ & $\begin{array}{l}0.19 \\
2.42\end{array}$ & $\begin{array}{r}0.21 \\
12.20\end{array}$ \\
\hline Total $\mathrm{x}$ & 24.62 & 24.13 & 22.79 & 23.54 & 27.46 & 25.28 & 25.34 & 25.96 \\
\hline \multicolumn{9}{|c|}{ Unsaturated fatty acids (UFA) } \\
\hline $\begin{array}{l}\mathrm{C}_{14: 1} \mathrm{x} \\
\mathrm{V}\end{array}$ & $\begin{array}{l}\operatorname{tr} \\
0.00\end{array}$ & $\begin{array}{l}\operatorname{tr} \\
0.00\end{array}$ & $\begin{array}{l}0.03 \\
2.16\end{array}$ & $\begin{array}{l}\operatorname{tr} \\
0.00\end{array}$ & $\begin{array}{l}\operatorname{tr} \\
0.00\end{array}$ & $\begin{array}{l}\operatorname{tr} \\
0.00\end{array}$ & $\begin{array}{r}0.04 \\
15.70\end{array}$ & $\begin{array}{l}0.03 \\
2.16\end{array}$ \\
\hline $\begin{array}{l}\mathrm{C}_{16: 1} \mathrm{x} \\
\mathrm{V}\end{array}$ & $\begin{array}{l}1.79 \\
6.72\end{array}$ & $\begin{array}{l}2.04 \\
6.52\end{array}$ & $\begin{array}{l}1.91 \\
7.34\end{array}$ & $\begin{array}{l}2.37 \\
9.28\end{array}$ & $\begin{array}{l}3.41 \\
8.33\end{array}$ & $\begin{array}{l}2.50 \\
6.22\end{array}$ & $\begin{array}{l}1.84 \\
2.40\end{array}$ & $\begin{array}{l}1.66 \\
6.49\end{array}$ \\
\hline $\begin{array}{l}\mathrm{C}_{18: 1} \mathrm{x} \\
\mathrm{V}\end{array}$ & $\begin{array}{r}26.76 \\
2.62\end{array}$ & $\begin{array}{r}28.75 \\
7.39\end{array}$ & $\begin{array}{r}30.68 \\
4.87\end{array}$ & $\begin{array}{r}34.14 \\
3.41\end{array}$ & $\begin{array}{r}29.90 \\
6.06\end{array}$ & $\begin{array}{r}31.96 \\
1.40\end{array}$ & $\begin{array}{l}29.46 \\
11.10\end{array}$ & $\begin{array}{r}32.74 \\
5.93\end{array}$ \\
\hline $\begin{array}{l}\mathrm{C}_{18: 2} \mathrm{X} \\
\mathrm{V}\end{array}$ & $\begin{array}{l}7.16 \\
4.00\end{array}$ & $\begin{array}{l}7.08 \\
2.14\end{array}$ & $\begin{array}{r}13.50 \\
2.80\end{array}$ & $\begin{array}{r}11.40 \\
0.60\end{array}$ & $\begin{array}{l}12.50 \\
18.20\end{array}$ & $\begin{array}{r}13.80 \\
7.86\end{array}$ & $\begin{array}{l}13.10 \\
11.90\end{array}$ & $\begin{array}{r}15.30 \\
6.30\end{array}$ \\
\hline $\begin{array}{l}\mathrm{C}_{18: 3} \mathrm{X} \\
\mathrm{V}\end{array}$ & $\begin{array}{l}\operatorname{tr} \\
0.00\end{array}$ & $\begin{array}{l}\operatorname{tr} \\
0.00\end{array}$ & $\begin{array}{l}1.34 \\
4.87\end{array}$ & $\begin{array}{l}1.24 \\
2.15\end{array}$ & $\begin{array}{l}1.48 \\
2.76\end{array}$ & $\begin{array}{l}1.44 \\
2.76\end{array}$ & $\begin{array}{l}1.28 \\
9.01\end{array}$ & $\begin{array}{l}1.63 \\
6.64\end{array}$ \\
\hline $\begin{array}{l}\mathrm{C}_{20: 1} \mathrm{X} \\
\mathrm{V}\end{array}$ & $\begin{array}{l}2.17 \\
2.96\end{array}$ & $\begin{array}{l}2.28 \\
2.01\end{array}$ & $\begin{array}{l}2.26 \\
1.96\end{array}$ & $\begin{array}{l}2.23 \\
1.71\end{array}$ & $\begin{array}{r}1.12 \\
12.10\end{array}$ & $\begin{array}{l}1.98 \\
2.46\end{array}$ & $\begin{array}{r}2.88 \\
22.60\end{array}$ & $\begin{array}{l}2.38 \\
3.02\end{array}$ \\
\hline $\mathrm{C}_{20: 2} \mathrm{x}$ & $\begin{array}{l}\operatorname{tr} \\
0.00\end{array}$ & $\begin{array}{l}\operatorname{tr} \\
0.00\end{array}$ & $\begin{array}{l}\operatorname{tr} \\
0.00\end{array}$ & $\begin{array}{l}\operatorname{tr} \\
0.00\end{array}$ & $\begin{array}{l}\operatorname{tr} \\
0.00\end{array}$ & $\begin{array}{l}\operatorname{tr} \\
0.00\end{array}$ & $\begin{array}{l}\operatorname{tr} \\
0.00\end{array}$ & $\begin{array}{l}\operatorname{tr} \\
0.00\end{array}$ \\
\hline Total $\mathrm{x}$ & 37.88 & 40.15 & 49.72 & 51.38 & 48.41 & 51.68 & 48.60 & 53.74 \\
\hline SFA/PUFA & 3.44 & 3.41 & 1.54 & 1.86 & 1.96 & 1.66 & 1.76 & 1.53 \\
\hline MUFA & 30.72 & 33.07 & 34.88 & 38.74 & 34.43 & 36.44 & 34.22 & 36.81 \\
\hline PUFA & 7.16 & 7.08 & 14.84 & 12.64 & 13.98 & 15.24 & 14.38 & 16.93 \\
\hline PUFA n-6/n-3 & 7.16 & 7.08 & 10.07 & 9.19 & 8.46 & 9.58 & 10.23 & 9.39 \\
\hline
\end{tabular}

tr=Acid content below the detect ability

In summary, it shoud be stated that A44 drakes and ducks in the $8^{\text {th }}$ and $9^{\text {th }}$ week of age were characterized by significantly higher dressing percentage and better musculature than in the $7^{\text {th }}$ week. Fatness of drakes and ducks carcasses in the $9^{\text {th }}$ week decreased by $1.1 \%$ and the meat : fat ratio was more profitable compared with the $8^{\text {th }}$ week. Basing on $\mathrm{pH}$ values, faulty meat of PSE and DFD was not found. Breast muscles of A44 ducks contained more water and protein but less fat than thigh and shank muscles. Together with age the protein content in breast and leg muscles was significantly increasing, whereas the fat content was significantly decreasing. Protein and fat content in breast and leg muscles of ducks in the tested periods of rearing indicated high nutrition value of A44 ducks' meat, however 9-week-old ducks' breast 
and leg muscles were distinguished by considerably higher protein content $(\mathrm{P} \leq 0.05)$ and lower fat content $(\mathrm{P} \leq 0.05)$ than 7 - and 8 -week-old ducks. The fatty acid profile analysis for duck muscles and fat showed that the tissues had a relatively good nutritive and processing value.

\section{Acknowledgements}

The research was supported by the Polish Committee for Scientific Research, grant No 2 PO6Z 04928.

ADAMSKI, M.:

Tissue composition of carcass and meat quality in ducks from paternal pedigree strain. Acta Sci. Pol. Zoot. 4 (2005), 3-12

ADAMSKI, M.; BERNACKI, Z.; KUŹNIACKA, J.:

The effects origin and sex on rearing results of ducks from two ancestral paternal strains. Acta Sci. Pol. Zoot. 4 (2005), 13-28

BAGLIACCA, M.; PACI, G.; MARZONI, M.; BIAGI, G.; AVANCI, C.F.:

Effect of Sorghum in diets for ducks. Arch. Tierz. 40 (1997), 277-286

BERNACKI, Z.; ADAMSKI, M.:

Evaluation of growth, slaughter traits and fatty acid content in breast muscles of ducks from two breeding lines. Zesz. Nauk. Przeg. Hod. 57 (2001), 455-465 [in Polish]

BOCHNO, R.; LEWCZUK, A.; WAWRO, E.:

Comparison of growth and rearing efficiency between Muscovy ducks and Pekin ducks. Acta Acad. Agric. Olst., Zoot. 37 (1992), 121-130 [in Polish]

BONS, A.; TIMMLER, R.; JEROCH, H.:

Changes in body composition and content of fat and protein in carcass of male and female Pekin ducks during growth. Zesz. Nauk. Przeg. Hod. 36 (1998), 165-175

BONS, A.; TIMMLER, R.; JEROCH, H.:

Changes in body composition and crude nutrient kontent of Pekin ducks during growth. Proceedings of $1^{\text {st }}$ World Waterfowl Conference. Taichung. 1-4 December (1999), 328-332

GRABOWSKI, T.:

An influence of factors affecting live animals on poultry meat quality. Pol. Drob. 10 (2002), 11-12 [in Polish]

GRAU, R.; HAMM, R.:

Eine einfache Methode zur Bestimmung der Wasserbindung im Fleisch. Fleischwirtschaft 4 (1952), $295-297$

ISGUZAR, E.; KOCAK, C.; PINGEL, H.:

Growth, carcass traits and meat quality of different local ducks and Turkish Pekins. Arch. Tierz. 45 (2002), 413-418

KIJANKO, T.; ZALEWSKI, K.; MAJEWSKA, T.:

Comparison of the composition of fatty acids in some tissues of mallards (Anas platyrhynchos L.) shot KISIEL, T.: off in summer or in the autumn. Zesz. Nauk. Przeg. Hod. 45 (1999), 65-72 [in Polish]

Tissue composition of carcass and some meat quality traits of ducks from pedigree strains. Zesz. Nauk. Przeg. Hod. 57 (2001), 517-518 [in Polish]

KISIEL, T.; KSIĄŻKIEWICZ, J.M.:

Comparison of physical and qualitative traits of meat of two Polish conservative flocks of ducks. Arch. Tierz. 47 (2004), 367-375

KOKOSZYŃSKI, D.; KORYTKOWSKA, H.:

The evaluation of meat traits of ducks from four pedigree strains. Acta Sci. Pol. Zoot. 4 (2005), 71-80 [in Polish]

KOKOSZYŃSKI, D.; KORYTKOWSKA, H.; ADAMSKI, M.; BERNACKI, Z.:

Evaluation of slaughter traits and proportion of fatty acids in breast muscles of strain A55 and P77 ducks. Rocz. Nauk. Zoot. Supl. 16 (2002), 317-321 [in Polish] 


\section{KSIĄŻKIEWICZ, J.M.:}

Comparison of reproduction and carcass traits in light type of ducks of four conservative flocks over eight generations. Arch. Tierz. 46 (2003), 377-389

KULASEK, G.; BARTNIKOWSKA, E.: Importance of unsaturated fatty acids in human and animal feeding. Part 1. Dietary sources, metabolism and requirement. Magaz. Wet. 3 (1994), 39-41 [in Polish]

MARUYAMA, K.; AKBAR, H. K.; TURCK, C. M.:

Growth pattern and carcass development in male ducks selected for growth rate. Br. Poultry Sci. 40 (1999), 233-239

MAZANOWSKI, A.; KSIĄŻKIEWICZ, J.M.:

Comprehensive evaluation of meat traits of ducks from two sire strains. J. Anim. Feed Sci. 13 (2004), 173-182

MAZANOWSKI, A.; KSIĄŻKIEWICZ, J.M.; KISIEL, T.:

Evaluation of meat traits in four-strain crossbred ducks. Rocz. Nauk. Zoot. 28 (2001) 1, 25-43 [in Polish]

PINGEL, H.:

Genetic and growth and meat production in water fowl. Poultry Breeding and Genetics. Elsevier, Amsterdam (1990), 691-704

PINGEL, H.; HEIMPOLD, M.:

Efficiency of selection for live weight and breast meat proportion in ducks. Arch. Tierz. 26 (1983), 435-444

PINGEL, H.; JUNG, S.:

Untersuchungen über die Selektion auf Brustmuskeldicke bei Enten. Arch. Tierz. 22 (1979), 281-286

PINGEL, H.; TRETTNER, K.:

Mast- und Schlachtleistungen von Moschusenten und deren Kreuzungen mit Pekingenten. Arch. Tierz. 30 (1987), 523-528

PFEUFFER, M.:

Physiologic effects of individual fatty acids in animal and human body, with particular attention to

POWELL, C.: coronary heat disease risk. Arch. Tierz. 44 (2001), 89-98

The domestic duck - a preliminary investigation of eating quality. Proceedings of $19^{\text {th }}$ World's Poultry Congress. WPSA. Amsterdam, Netherlands. 20-24 September (1992), 106-108

SHAHIN, K.; SHEMEIS, A.R.; ABDALLAH, O.Y.; SALEH, K.:

Effects of genetic control of subcutaneous fat deposition via using restricted selection indexes on life performance and carcass characteristics of Pekin ducklings. Arch. Tierz. 43 (2000), 69-77

SMULIKOWSKA, S.:

Poultry nutrition norms. Institute of Physiology and Animal Feeding. Iss. III, (1996), 77-82 [in Polish]

WAWRO, K.; WILKIEWICZ-WAWRO, E.; KLECEK, K.; BRZOZOWSKI, W.:

Slaughter value and meat quality of Muscovy ducks, Pekin ducks and their crossbreeds, and evaluation of the heterosis effect. Arch. Tierz. 47 (2004), 287-299

WITKIEWICZ, K.:

Zoometric measurements, slaughter value and chemical composition of the breast muscle in two strains of ducks of Pekin type. Rocz. AR Pozn. Zoot. 330, 52 (2000), 231-240 [in Polish]

WITKIEWICZ, K.; KONTECKA, H.:

Fatty acid content in duck breast muscle. Zesz. Nauk. Przeg. Hod. 61 (2002), 149-150 [in Polish]

ZIOŁECKI, J.; DORUCHOWSKI, W.:

Methods of Evaluation Poultry Slaughter Value. COBRD, Poznań (1989), 1-22 [in Polish]

Received: 2007-11-13

Accepted: 2008-03-08

Author:

Dr. BARBARA WITAK

Department of Breeding Methods, Poultry and Small Ruminant Breeding

University of Podlasie

08-110 Siedlce

Poland

email: bwitak@ap.siedlce.pl 